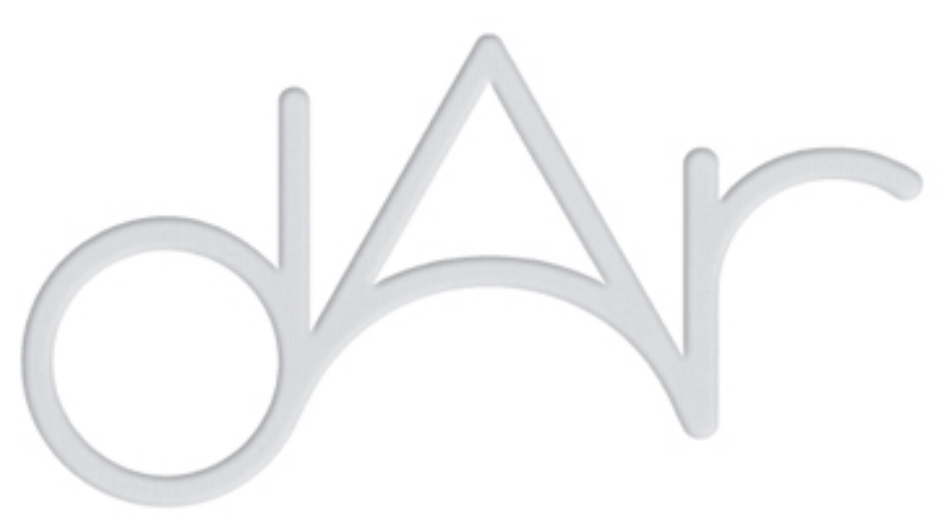

\title{
Corpos estranhos: diferenças étnicas e construções raciais na cultura visual do
} Renascimento

\author{
Autor(es): $\quad$ Goulão, Maria José \\ Publicado por: Centro de Estudos em Arqueologia, Artes e Ciências do Património \\ URL \\ persistente: URI:http://hdl.handle.net/10316.2/39300 \\ DOI: $\quad$ DOI:http://dx.doi.org/10.14195/2182-844X_2_5
}

Accessed : $\quad$ 26-Apr-2023 08:55:38

A navegação consulta e descarregamento dos títulos inseridos nas Bibliotecas Digitais UC Digitalis, UC Pombalina e UC Impactum, pressupõem a aceitação plena e sem reservas dos Termos e Condições de Uso destas Bibliotecas Digitais, disponíveis em https://digitalis.uc.pt/pt-pt/termos.

Conforme exposto nos referidos Termos e Condições de Uso, o descarregamento de títulos de acesso restrito requer uma licença válida de autorização devendo o utilizador aceder ao(s) documento(s) a partir de um endereço de IP da instituição detentora da supramencionada licença.

Ao utilizador é apenas permitido o descarregamento para uso pessoal, pelo que o emprego do(s) título(s) descarregado(s) para outro fim, designadamente comercial, carece de autorização do respetivo autor ou editor da obra.

Na medida em que todas as obras da UC Digitalis se encontram protegidas pelo Código do Direito de Autor e Direitos Conexos e demais legislação aplicável, toda a cópia, parcial ou total, deste documento, nos casos em que é legalmente admitida, deverá conter ou fazer-se acompanhar por este aviso.

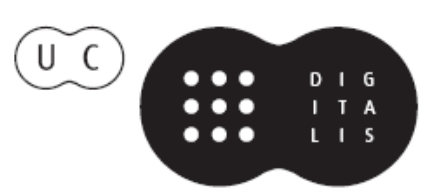




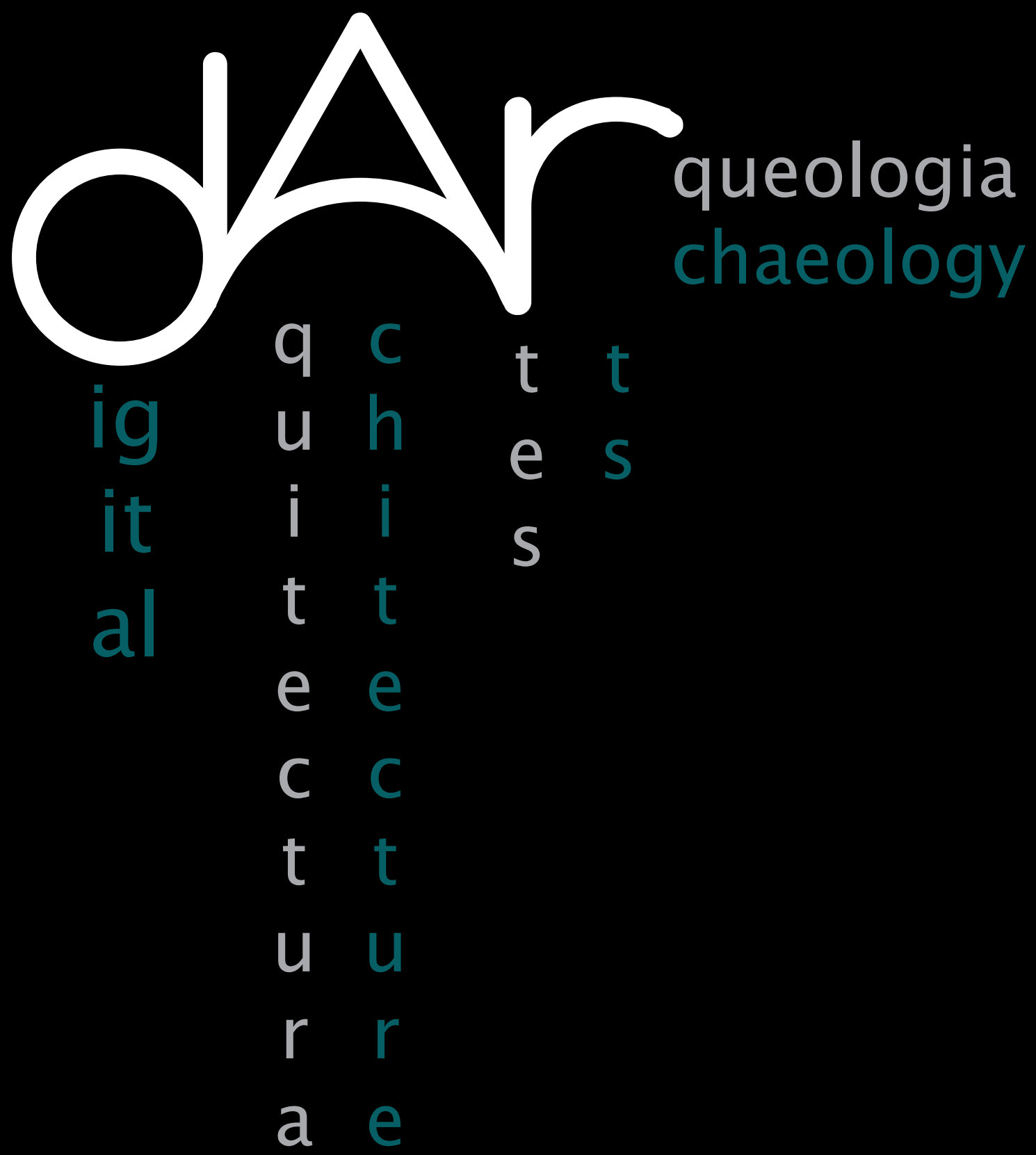




\title{
CORPOS ESTRANHOS: DIFERENÇAS ÉTNICAS E CONSTRUÇÕES RACIAIS NA CULTURA VISUAL DO RENASCIMENTO
}

\author{
Maria José Goulão* \\ FBAUP - Faculdade de Belas Artes da Universidade \\ do Porto \\ CEAACP - Centro de Estudos em Arqueologia, \\ Artes e Ciências do Património
}

\begin{abstract}
RESUMO
É no Renascimento que a Europa, influenciada pelas viagens de navegação e exploração, manifesta um interesse renovado pela representação do corpo extra-europeu. A inclusão de novos continentes no campo de visão europeu dará origem a novas formas de representação, que correspondem por vezes a formas de não-visão, ou de visão distorcida. A Europa irá representar o corpo estranho do Outro, negociando a sua imagem de forma a incorporar spolia e exotica, mas não se esgota nestas "excentricidades". Saberá também classificar a novidade dentro de categorias familiares, procurando proximidades e semelhanças que assumem os costumes europeus como ponto de partida.

O nativo americano não é assim construído como um Outro radicalmente diferente, mas antes traduzido num arquétipo familiar, governado pela lógica da similitude e conformado aos mundos estranhos, mas relativamente confortáveis para a mente europeia, já antes imortalizados nos textos da Antiguidade e continuados nas narrativas de viagens mais recentes.
\end{abstract}

Palavras-chave: Cultura visual, Renascimento, iconografia, figuração do índio, homem selvagem

\section{ABSTRACT}

It is in the Renaissance that Europe, influenced by navigation and exploration travels, showed a renewed interest in representing the extra-European body. The inclusion of new continents in the European field of vision will give way to new forms of representation that sometimes correspond to forms of non-vision, or distorted vision. Europe will represent the foreign body of the Other, negotiating its image in order to incorporate spolia and exotica, but it will not exhaust itself in those "eccentricities". Europeans will also try to sort the novelty within familiar categories, looking for proximities and similarities that assume European customs as a starting point.

The image of Native Americans is thus not constructed as a radically different Other, but rather translated into familiar archetypes, governed by the logic of similarity and conformed to worlds that, although strange, were quite comfortable for the European mind, since they had already been immortalized in earlier texts of antiquity and followed in the narratives of more recent trips.

Keywords: visual culture, Renaissance, iconography, Indian, wild man. 
A temática do corpo tornou-se central nas humanidades e nas ciências sociais sensivelmente a partir da década de 80 do século XX, assumindo-se hoje em dia como uma espécie de fronteira última da transdisciplinaridade. ' A história da arte não tem sido alheia a este tema, tendo-se preocupado em compreender como é que a imagem do corpo se relaciona com a ordem ou com a desordem social, com questões de identidade, normalidade e monstruosidade. No entanto, o corpo do Outro, ao assumir um lugar descentrado em relação à história da arte tradicional, que é ainda hoje vincadamente eurocêntrica, tem levado o seu tempo a constituir-se como objecto de atenção e estudo desta disciplina. Como exemplo, a notável Histoire du corps, dirigida por Georges Vigarello (Vigarello, Courtine e Courbin, 2008), não contém uma única linha dedicada ao corpo colonial, extra-europeu, ou ao modo como as viagens de descobrimento revolucionaram as diversas leituras sobre o corpo.

A questão que nos preocupa aqui é justamente esta: a forma como as artes visuais da Europa renascentista conceberam, e lidaram, com o corpo dos habitantes dos novos territórios durante o que alguns chamaram já "o longo século XVI" (1480-1610), numa altura em que ainda não estávamos condicionados pelo imperialismo e colonialismo subsequentes, que viriam a ser responsáveis por outro tipo de preconceitos raciais.

A perspectiva a partir da qual abordamos esta questão assenta não na noção de culturas nacionais definidas e estanques, mas sim nas trocas culturais e nos processos culturais transnacionais (Farago, 1995, pp. 67 e 68). Ora o contacto intercultural é, entre outras coisas, um encontro de pessoas concretas, de indivíduos de carne e osso, que trazem consigo uma bagagem milenar: linguagens, códigos de comportamento, histórias, instituições, tecnologias, em resumo, tudo o que constitui uma cultura. Antes mesmo de serem ditas quaisquer palavras, o encontro com o Outro, ou seja, o contacto entre culturas, é sempre um face-a-face mediado de forma crucial pela visão. Não poucas vezes, este contacto visual traz consigo mal-entendidos, a distorção ou mesmo a desfiguração do Outro. Este encontro de olhares, longe de ser mútuo, torna-se uma recriação das relações de poder, um local de ansiedade mútua, de ressentimento e de culpa, saldando-se em estereótipos, que são imagens predominantemente visuais, caricaturas que violentam os povos que representam. Aquilo a que chamamos racismo não é, assim, uma mera atitude, mas uma forma de ver, a forma de ver da cultura dominante. A experiência de ver e ser visto é "socialmente construída", ao mesmo tempo que se constitui como um momento fundacional na construção do social. As instituições visuais permitem mediar as fronteiras entre os povos, mas são simultaneamente responsáveis por vários bloqueios, através de práticas de observação, de representação, de vigilância, mas também através de uma certa cegueira e de modos de invisibilidade (Mitchell, 1995, pp. 292-293).

Propomo-nos pois tratar de fenómenos de estranhamento e de familiaridade nas representações renascentistas da diferença, tendo presente que na construção cultural do Outro exótico está em jogo não só um corpo objectivado, o corpo como objecto, mas também o corpo subjectivo, cuja compreensão é bastante complexa.

Só do século XIX em diante, já no contexto do pensamento contemporâneo, é que a noção de raça, baseada na lógica da oposição Eu-Outro, foi usada como um princípio organizador para catalogar as diferenças entre os homens. Podemos afirmar que a época pré-moderna teve um pensamento baseado em considerações raciais, ou que houve um "proto-racismo", mas ao fazê-lo estamos certamente a impor um tipo de raciocínio contemporâneo para sustentar tradições de pensamento de outras épocas históricas, caindo no anacronismo (Seth, 2010, pp. 3-5 e 45).

O termo "raça" não tinha assim no Renascimento o significado contemporâneo, não querendo isto dizer que não existisse um discurso de inflexões 
raciais sobre a cor, ou certas percepções da cor racial veiculadas de outro modo que não através do vocabulário tradicionalmente ligado ao exotismo e à teologia (Erickson, 1993).

A partir de finais do século $X V$, deu-se uma mudança significativa na maneira de pensar sobre a pluralidade e diversidade do mundo, na esteira dos contatos com a África, o Sudeste da Ásia e as Américas. Até esta altura, o mundo para lá das fronteiras da Cristandade era visto como o reino da confusão e do caos, da natureza ameaçadora e desordenada, dos monstros e dos seres fantásticos. A passagem do fantástico ao real, da "bestialidade" ao humano, fez-se através da conjugação das viagens de descobrimento, do comércio internacional e da energia artística galvanizada pelo humanismo, responsáveis pelo colapso de um mundo essencialmente hermético e eurocêntrico, pelo recuo do maravilhoso e pela lenta construção de uma nova imagem da humanidade, na qual se inserem as novas concepções e atitudes em relação aos habitantes daquelas partes do globo.

As novas realidades vêm revolucionar o pensamento pré-existente acerca do homem e da sua natureza, permitindo denunciar como ilusão a antropologia monstruosa até aí aceite, que entrou em descrédito. Contudo, estas tentativas de descrever os povos não-europeus em termos menos vagos do que "o Outro" foram um processo lento, não-linear e complexo, constituindo olhares que não raras vezes assumiram formas de "não-visão", ou de visão distorcida.

\section{O HOMEM SELVAGEM}

A literatura grega da Antiguidade fazia menção a um vasto conjunto de seres arquetípicos; estas raças de formas humanas aberrantes viveriam na Índia, na Etiópia, na Líbia e noutras terras remotas. Esta tradição foi continuada ininterruptamente até à Idade Média, em histórias naturais, cosmologias, crónicas e enciclopédias, reunidas sob o termo genérico de Maravilhas do Oriente. Plínio,
Solino ou Marciano Capela constituem as fontes principais destes textos medievais, sendo Santo Agostinho o primeiro autor cristão a discutir as raças monstruosas. As suas opiniões serão adoptadas por outros que se lhe seguiram, como Isidoro de Sevilha, Rabão Mauro ou Vicente de Beauvais. Estes textos vão sendo progressivamente amplificados e reelaborados, mas as descrições das raças monstruosas, não havendo delas uma experiência real que permitisse desmontar as lendas, mantêm-se imutáveis. Estas descrições minuciosas do Outro foram retomadas e desenvolvidas nas obras atribuídas a Marco Polo (no início do séc. XIV) ou ao cavaleiro anglo-normando Jehan Mandeville (no final do séc. XIV), cuja obra O Livro das Maravilhas do Mundo terá sido a que mais circulou, conhecendose 300 cópias manuscritas, e cerca de 90 edições impressas, já do século XVI.

A mentalidade cristã medieval aceitou a antropologia monstruosa, considerando estes seres como uma "anomalia normal", como um desvio da Natureza, e nunca como uma transgressão da ordem natural (Sebastián López, 1988, p. 54). É como filhos de Adão que Santo Agostinho os apresenta, em A Cidade de Deus, criando uma visão ecuménica, à qual são convocados todos os homens, mesmo os que têm formas estranhas e monstruosas.

As raças monstruosas, os prodígios e os seres fantásticos situavam-se nos limites do mundo conhecido e familiar; definiam a sua fronteira, servindo, desde a Antiguidade, como marcos de uma geografia remota. Encontrando-se ao serviço das culturas que Ihe haviam dado origem, o maravilhoso permitia ainda fornecer um arremedo de moralidade: através dele, era possível estabelecer-se uma base conceptual e uma explicação moral das coisas que estavam para além do mundo conhecido, ou remeter para tudo o que era contrário à norma, através de uma visão ao espelho de um mundo "do avesso" (Leitch, 2010, p. 27).

A figuração do homem selvagem, que se encontra ligada, na imaginação ocidental, à concepção do Outro civilizacional, vai 
adquirir forma a partir de características destes seres monstruosos, que sintetiza. O tema do homem selvagem, que se espalhou por toda a Europa, funcionou como um mito, ocupando um lugar destacado no imaginário ocidental como amostra de um "mundo às avessas", e foi objecto de sentimentos antitéticos de repulsa e de sedução. Preencheu sem dúvida um espaço importante no universo ambíguo do maravilhoso e do desconhecido. Enquanto símbolo, remete para a imagem ao espelho do homem medieval, representando todo um conjunto de pulsões recalcadas e funcionando ora como elemento moralizador, por contraposição, ora como escape de tensões de vária ordem, por afirmação. A sua origem literária parece clara, bem como a sua relação com as forças brutas da natureza, e, logo, com a não-civilização, em contraste declarado com a ordem do universo medieval.

Em Portugal acompanhou-se de tal forma a voga da figuração do homem selvagem que, como acontecia na maior parte das cortes europeias, aparece frequentemente referida a sua participação em momos, desfiles, festas e representações teatrais. Denunciando a sua origem literária, o homem selvagem ultrapassa os limites das artes visuais para surgir integrado em mascaradas e outros divertimentos cortesãos. Assim aconteceu quando do casamento de Dona Leonor, irmã do rei D. Afonso V, com o imperador Frederico III da Alemanha, em 1451. Rui de Pina, na Crónica do Senhor Rei D. Afonso V, relata como foi este casamento e as festas que por ele se fizeram; a certa altura, o rei desafiou os cavaleiros para justas reais, A que o Yfante Dom Fernando veo com seus ventureiros vestidos de guedelhas de seda fina como

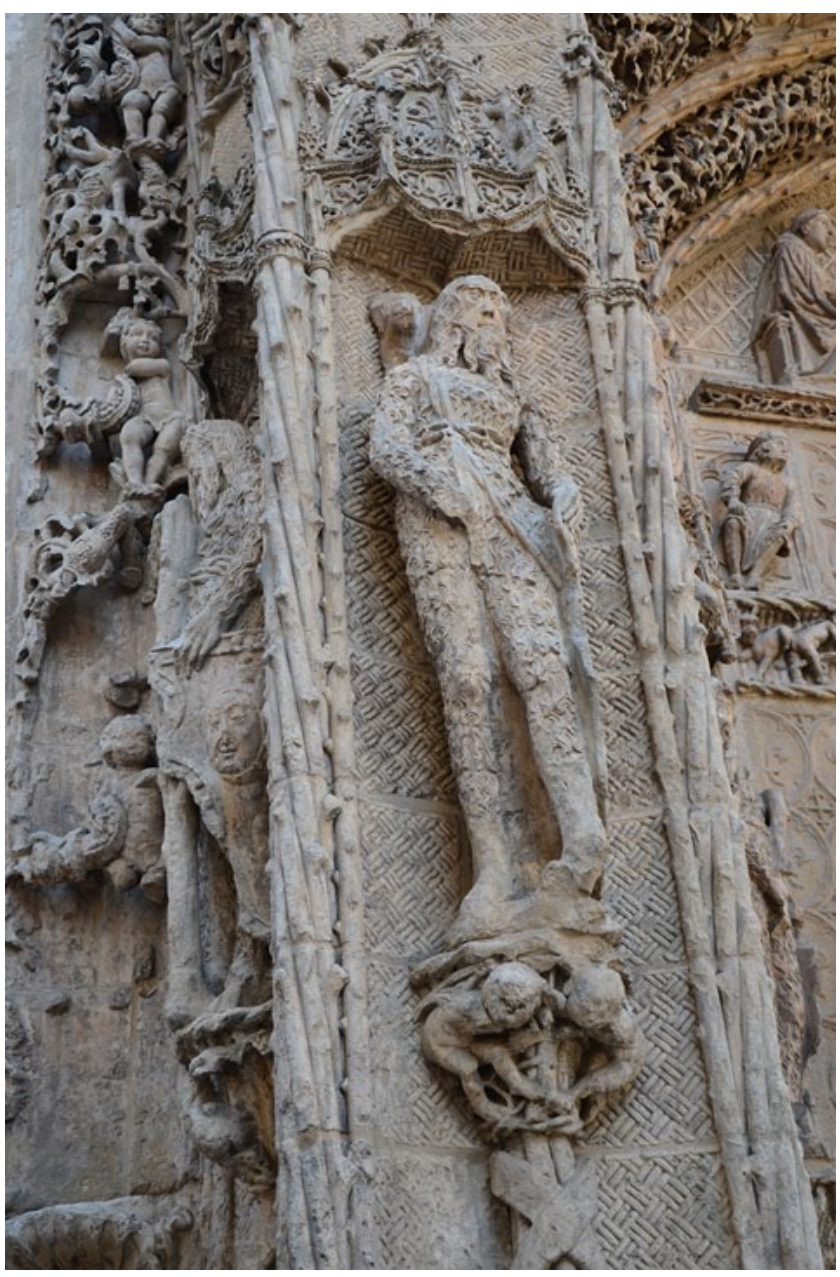

Fig. 1 - Homens selvagens, portal do Colégio de S. Gregório de Valladolid, 1488-96, atribuído à oficina de Gil de Siloé. 
salvajens, em cima de bõos cavallos (Pina, 1977, p. 761).

Num romance de cavalaria, publicado pela primeira vez em 1567, da autoria de Jorge Ferreira de Vasconcelos, e intitulado Memorial das proezas da segunda Távola Redonda, descreve-se um torneio feito em Lisboa em 1552, em honra do príncipe D. João; aí se menciona Hum salvagem vestido de peles, com huma cabeleyra que the chegava ate os giolhos, e na mão esquerda hum arco com huma frecha nelle. Mais à frente, no mesmo capítulo, descreve-se um barco cuberto de folhas de era, ho qual remavam nove salvages vestidos de musgo, e os capelinhos, e outro que ho governava, todos de mazcaras (Vasconcelos, 1867, pp. 330 e 348).

As formas mais precoces de registo visual dos habitantes das novas paragens dão-se em resultado de encontros que escapam já aos desígnios da cruzada religiosa e da peregrinação, e que ocorrem, pelo contrário, num contexto atento ao relativismo e à vasta diversidade do mundo (Leitch, 2010, p.101). No entanto, a realidade encontrada não escapa a uma interpretação ditada pela expectativa criada pelas narrativas de viagem medievais. Cristóvão Colombo, na sua De insulis inventis Epistola, texto datado de 1493 e repetidamente impresso em numerosas traduções, que permitiu aos europeus saber da viagem do navegador pelas suas próprias palavras, descreve as ilhas que visitou, afirmando que não se deparou com as monstruosidades de forma humana que muitos esperavam que habitassem essas regiões longínquas. Porém, não deixa de referir que encontrou canibais e que ouviu relatos de uma ilha habitada só por mulheres.

A facilidade e a credulidade com que o Renascimento aceitou o homem selvagem e as outras criaturas com ele aparentadas, que haviam dominado a imaginação medieval, não é de estranhar. Sabemos que Colombo levou consigo três livros na sua primeira viagem; eram eles a Imago Mundi de Pierre d'Ailly, um astrólogo e teólogo francês do século XIV-XV, as Viagens de
Marco Polo, e a História Natural de Plínio. Estando amplamente familiarizado com as monstruosidades semi-humanas descritas nos textos dos antigos, representadas na arte medieval, e relatadas pelos viajantes, não é de surpreender que Colombo esperasse encontrar algo mais do que humanos nas suas viagens (Seth, 2010, p. 39). Também Duarte Pacheco Pereira, no seu Esmeraldo de Situ Orbis, atribui a designação de selvagens quer a alguns africanos do Sara, quer aos chimpanzés da Serra Leoa, referindo-se a estes como homens selvagens, a que os antigos chamam Sátiros, e são todos cobertos de um cabelo ou sedas quási tão ásperas como de porco (Pereira, 1988, Primeiro Livro, cap. 25, p.91 e cap. 33, pp. 117-119).

É assim à iconografia do homem selvagem que os homens do Renascimento vão genericamente buscar inspiração para tornarem o Outro não apenas comensurável, mas familiar. $\mathrm{Na}$ epistemologia do Renascimento, o Outro é traduzido (no sentido de tornar inteligível) para um arquétipo familiar, que se adaptava aos mundos estranhos, mas de alguma forma confortáveis, que já haviam sido imortalizados nos textos da Antiguidade e nas narrativas de viagens medievais. $^{2}$

\section{O ÍNDIO}

O corpo do índio americano não é uma realidade objetiva e permanente, mas uma construção mental, uma pura imagem criada pelos europeus. Na verdade, os europeus inventaram o índio, mais do que o encontraram, da mesma forma que a América não foi descoberta, mas inventada pelos europeus do século XVI. Basta lembrar como exemplo as palavras do humanista espanhol Hernán Pérez de Oliva, que em 1528 escreve que Cristóvão Colombo organizou a sua segunda expedição para misturar o mundo e dar àquelas terras estranhas a forma das nossas (Sebastián, 1990, pp. 433-434).

Na época que se seguiu aos primeiros encontros, o desafio intelectual colocado aos cronistas consistia em 
descrever e classificar os modos de vida e comportamentos dos índios através dos modelos europeus tradicionais. Não dispondo de utensílios conceptuais adaptados, procuram a sujeição das novidades encontradas a modelos culturais e critérios taxonómicos europeus. Tudo o que é estranho e exótico capta primeiro a atenção dos autores dos relatos iniciais, da mesma forma que nas artes visuais passam a ser valorizados os aspectos que são diferentes ou insólitos.

A visão do Outro transmitida pela literatura da época tem outra característica para nós relevante: é globalizante, não contemplando o retrato, já que o encontro se realiza no plano colectivo e nunca no plano individual. Tal facto terá igualmente as suas consequências na representação plástica do índio, que surge quase sempre como um "tipo", desprovido de aspectos fisionómicos particulares.

Os índios americanos são apresentados, de modo contraditório, simultaneamente como modelo da razão universal, da liberdade, da igualdade e da individualidade, e como um desvio a essas mesmas normas universais. Esta visão contraditória, que situa os indígenas do Novo Mundo nos extremos da escala ontológica, espelha a forma como estes novos homens são classificados nas crónicas de viagens da época. O índio americano é ora visto como um ser primitivo, inocente e puro, não contaminado pelos vícios da civilização ocidental, e como tal particularmente apto a receber o dom da palavra divina desde que tivesse uma instrução adequada (Albuquerque, 1990, pp. 40-41), ora apresentado como bárbaro e selvagem, salientando-se a antropofagia, a nudez, a falta de crenças religiosas, a inexistência de uma organização social e política estável, a poligamia, a sexualidade desbragada, os sacrifícios humanos ou a idolatria, que repugnavam particularmente aos europeus e contribuíram para criar uma imagem negativa (Pereira Iglesias, 1993).

O que parece ser uma das mais precoces figurações europeias dos ameríndios foi recentemente posta a descoberto em Itália, durante o restauro de um fresco pertencente ao Vaticano, que representa a Ressurreição de Cristo. A pintura, atribuída a Pinturicchio, foi terminada em 1494, apenas dois anos após a chegada de Cristóvão Colombo ao Novo Mundo, e há cerca de 500 anos que decora as paredes dos Apartamentos dos Bórgia, mas só recentemente foi sujeita a restauro. O pequeno grupo de índios, que estava invisível e coberto por sujidade, foi posto a nu por uma restauradora, em 2006. A descoberta esteve vários anos oculta e só muito recentemente foi revelada por Antonio Paolucci, director dos Museus do Vaticano. Paolucci sugere que estas figurinhas de homens nus, cujo único traço de exotismo é constituído pelos toucados de penas que exibem e pelos movimentos agitados da dança ritual que executam à volta de um poste, foram inspiradas pelas descrições das tribos americanas
Fig.2 - Pinturicchio, Ressurreição de Cristo (detalhe), 1494, fresco, Apartamentos dos Borgia, Vaticano, Itália.

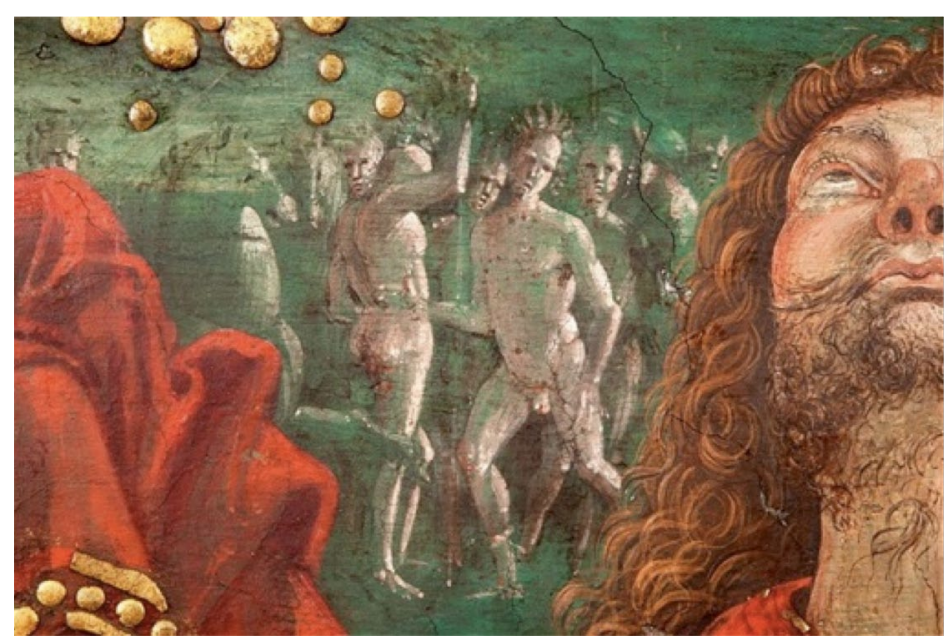


trazidas por Colombo na viagem de retorno. Não esqueçamos que o Papa da época, Alexandre VI, era um espanhol, Rodrigo Borgia, e que o Vaticano estaria empolgado com as novas descobertas, que não passaram certamente despercebidas na corte papal.

As imagens convencionais do Novo Mundo que acompanhavam os relatos das viagens marítimas impressos em Itália ou na Península lbérica contrastam com as ilustrações produzidas em Augsburgo. Com efeito, os gravadores alemães souberam apresentar os traços distintivos dos povos não-europeus de forma inovadora e original. As gravuras de Hans Burgkmair respeitantes às Índias Orientais (Povos da África e da Índia, c. 1508) foram das primeiras a libertar os nativos das amarras de uma tradição visual de exotica que os colocava junto com os seres fantásticos, as raças monstruosas, os homens selvagens e o Outro bárbaro, considerando-os, pelo contrário, plenamente humanos. Tal facto deve-se ao ambiente humanista, patrício e mercantil em que estes gravadores evoluíam (Leitch, 2010, pp. 1-2).

Como Greenblatt (1991, p. 6) observou, há uma ligação crucial entre mimesis e capitalismo: na moderna ordem mundial, o desabrochar do capitalismo permitiu que a proliferação e circulação de representações (e os instrumentos para gerar e transmitir imagens) atingissem uma magnitude global verdadeiramente espectacular e incontornável. A vontade e a capacidade de transpor enormes distâncias e de, na busca do lucro, encontrar e representar espécies naturais e seres humanos que não eram familiares, dão origem às experiências particulares de que aqui tratamos, surgidas justamente num contexto pré-capitalista dos mais avançados da época, como é o caso de Augsburgo.

As imagens que contavam realmente, as que podemos considerar "capitais", são as que adquiriram capacidade reprodutiva, mantendo-se e multiplicando-se de formas sempre novas. Esta capacidade produtiva da representação faz com que as imagens não sejam meros produtos, mas surjam também como produtoras, ao terem o poder de alterar decisivamente as forças que as criaram (Greenblatt, 1991, p. 6).

Os mercadores-banqueiros de Augsburgo, como os Welser e os Fugger, dominavam uma rede comercial intercontinental e faziam parceria com humanistas e artistas, aos quais entregavam relações escritas e artefactos dos territórios recém-descobertos: papagaios, amostras de arte plumária sulamericana, esquissos que deram origem a estudos preparatórios para as gravuras de Burgkmair, e até espécimes humanos vivos, que eram conservados nas suas casas. ${ }^{3}$ É nesta região que se detecta a eclosão de um novo vocabulário visual que passa a ser usado pelos artistas para representar a diferença racial. Segundo Leitch $(2010$, p. 5), estas práticas são precursoras da taxonomia e de outros gestos protocientíficos como a etnografia.

O caso mais precoce é o de Hans Burgkmair e da sua representação etnograficamente rigorosa dos indígenas do Índico, na xilogravura O Cortejo do Rei de Cochim, impressa em 1508, e que integra o friso denominado Povos da África e da Índia. Aqui, encontramos um afastamento bastante sensível em relação aos estereótipos anteriormente divulgados. Os nativos surgem agrupados em células familiares, os seus corpos são bem proporcionados e modelados segundo os princípios perspécticos do Renascimento italiano. Muito provavelmente terá sido a família Welser a encomendar a Burgkmair estas gravuras inspiradas no relato de Balthazar Springer sobre a primeira viagem feita por mercadores alemães em 1505-6 às Índias Orientais portuguesas, onde os Welser participaram com três navios, integrados na frota do vice-rei Francisco de Almeida. Gravador e escritor teriam sido postos em contacto através do humanista e secretário da cidade de Augsburgo, Konrad Peutinger, próximo da família Welser, pois era casado com Margarete, irmã de Anton Welser o Jovem. Sabemos que textos vernaculares como os de Vespúcio e de Vasco da Gama encontraram precocemente aceitação e credibilidade junto de Peutinger. Entre 1506 
e 1507, o impressor Valentim Fernandes, natural da Morávia, na Alemanha, que se fixara em Portugal antes de 1490, onde publicou várias obras, ocupou-se em reunir uma série de relatos manuscritos das viagens de exploração portuguesas destinados aos Welser. Num inventário da biblioteca de Peutinger datado de 1597 (Inventarium bibliothecae Peutingerianae, Bayerische Staatsbibliothek, Munique, Clm 4021 d, fol. 43r, no. 163), são mencionados estes textos em latim e português, sob a designação De Insulis et peregrinatione Lusitanorum: liber manuscriptus. Conservase actualmente também na Bayerische Staatsbibliothek de Munique um códice (Cod. Hisp. 27: Berichte aus Portugal zur Entdeckung Afrikas und Indiens) que inclui relatos sobre a costa oriental Africana escritos pelo próprio Valentim Fernandes, e vários textos relativos à descoberta e conquista da Guiné. No mesmo códice, encontra-se uma transcrição portuguesa da missão de D. Francisco de Almeida na Índia, da autoria do cronista oficial da família Welser, Hans Mayr. ${ }^{4}$

As xilogravuras dos Povos da África e da Índia tornaram-se conhecidas e circularam em diversas versões com um grau variável de fidelidade ao original. No entanto, as contribuições que poderiam trazer para uma descrição etnográfica precisa foram ignoradas sistematicamente, tendo as imagens cuidadosamente descritivas de
Burgkmair sido pirateadas por ilustradores de marginalia de livros impressos, e sacrificadas às exigências da lógica economicista das oficinas de gravação e impressão, sendo recicladas nos putti adornados de penas dos panfletos da Reforma. Foram cortadas, isoladas, recombinadas e reutilizadas, como modelos reduzidos à sua essência. Esta recomposição usando os mesmos blocos de madeira gravados era bastante comum nos primeiros tempos da história da imprensa escrita e da gravura (Leitch, 2010, p.149).

A pouco e pouco, no âmbito da cultura visual alemã impressa de 1520 a 1550 , iremos encontrar assim estes habitantes das Américas despojados da ferocidade das primeiras representações e infantilizados, retratados como tipos decorativos familiares, como putti exuberantes, ou como pobres de espírito inocentes (Leitch, 2010, p.147).

Este género de interpretação bastante livre da figura do índio, revelador de uma destabilização e de um desmantelamento progressivo do tema, encontra-se, por exemplo, nos relevos da segunda capela do claustro do mosteiro de Lorvão, em Portugal, datada de 1602 e atribuída ao círculo de João de Ruão, cuja decoração segue modelos da Renascença, adaptados ao gosto maneirista. Neste caso, duas figurinhas masculinas de fisionomia europeia adquirem o significado exótico de índios

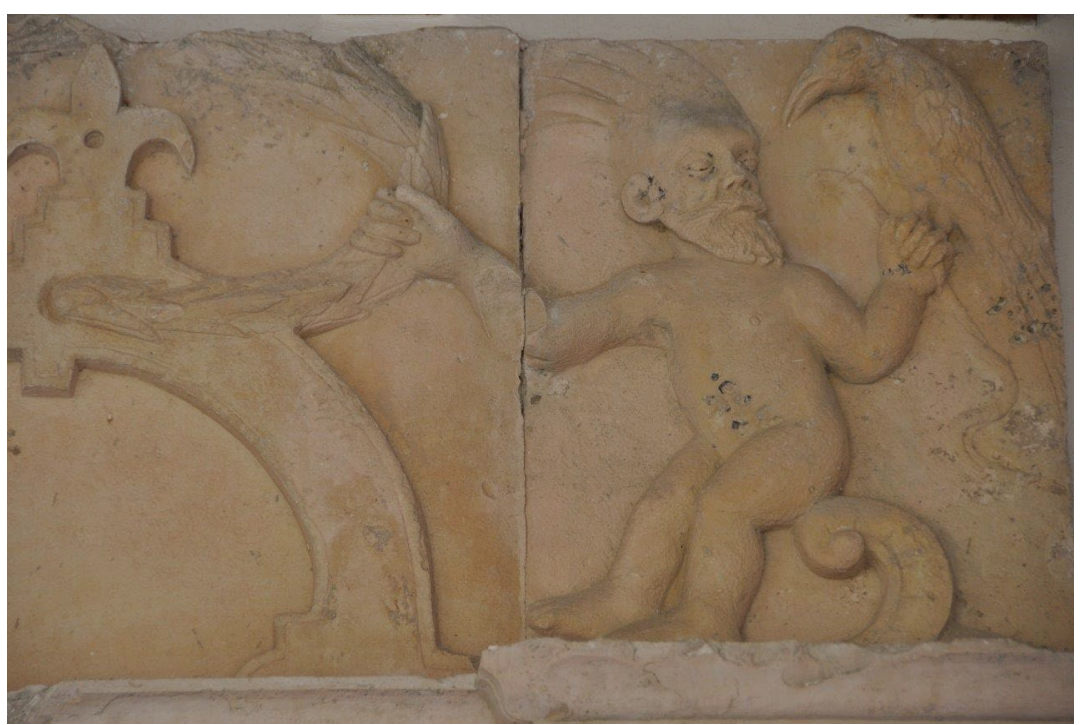

Fig.3 - Baixo-relevo da segunda capela do claustro do mosteiro de Lorvão, Portugal, 1602, atribuído ao círculo de João de Ruão. 
do Brasil através dos toucados semelhantes a longas penas, e dos papagaios que ostentam nas mãos (Borges, [2001], p. 229). Esta figuração inócua do nativo americano, relegado para um papel de Outro decorativo, surge aqui como herdeira da tradição simbólica e alegórica que já vinha da Antiguidade é que é comum a grotescos, intermezzi, disparates e outros divertimentos bizarros e insólitos do período da maneira. ${ }^{5}$

Quando os habitantes do Novo Mundo começaram a ser representados, a Europa normalmente reciclou aquilo que lhe era próprio de forma a descrever estes novos povos, num esforço para compreendê-los através da visualidade. Recorre-se a todos os seres naturais e em estado de nudez, como Adão e Eva, o homem selvagem ou a mulher selvagem, encarados como duplos dos habitantes destas regiões. As primeiras representações destes novos vizinhos, mesmo quando não são simples reciclagens, dão muito pouca importância ao naturalismo. O homem selvagem, cuja tradição iconográfica já existia há muito, impôs-se pois frequentemente como modelo visual para os habitantes do Novo Mundo (Leitch, 2010, pp. 6 e 12-13).

É necessário considerarmos aqui igualmente o impacto da Ásia na invenção da América. A tradição visual deste período é altamente fluída e não-compartimentada; as divisões convencionais da cartografia não se adequam à geografia mental dos europeus do início da época moderna. Sabemos que o descobrimento da Ásia, da Índia e da América não foram acontecimentos claramente distintos, tal como a historiografia contemporânea os vê; esta distinção não existia antes das viagens de circum-navegação (1519-1522). Com efeito, Cristóvão Colombo dirigia-se supostamente para a Ásia quando atingiu as costas americanas; para além do mais, o conhecimento geográfico rigoroso era circunscrito a um grupo muito restrito de sábios; o senso comum não se preocupava com esta distinção. A separação clara entre a Índia e as Américas, própria do pensamento contemporâneo, é um anacronismo para a época, confirmado pelo facto de nos primeiros relatos visuais da época moderna a figuração do índio americano e do índio oriental serem usadas de forma indistinta, muito tempo depois de esta indefinição já ter sido posta em causa, após 1492. Ameríndios, asiáticos, bárbaros e homens selvagens eram quase intermutáveis (Leitch, 2010, p. 12).

Embora entre os últimos anos do séc. XV e 1510 as gravuras que circularam na Alemanha representando os nativos do Novo Mundo começassem por reciclar a imagética do homem selvagem, que tradicionalmente significava a inversão da cultura europeia (uma figura rudemente vestida, belicosa por natureza, sem regras sociais, sem língua reconhecível), os ilustradores alemães vão refinando esta imagem à medida que chegam à Europa artefactos americanos que complementam a informação das testemunhas presenciais dos primeiros encontros. Um toucado e um saiote de penas, baseados no trajo dos Tupinambá que os primeiros navegadores encontraram no Brasil, tornam-se um distintivo iconográfico bastante comum, permitindo criar uma imagem mais específica e verídica para aludir à alteridade do que a do tradicional protótipo do homem selvagem. A iconografia extremamente maleável do homem selvagem acomoda facilmente estes novos seres, e permite conceber o desconhecido através do conhecido. Segundo Leitch, ao contrário dos ilustradores alemães, os artistas de outras regiões europeias não provêm de uma tradição visual tão marcada pelo mito do homem selvagem, pelo que não o usam de forma tão evidente como auxiliar na composição da figura do índio (Leitch, 2010, pp. 54 e 57).

Na Alemanha, o mais antigo exemplo da evolução para uma preocupação realmente etnográfica a partir da figura do homem selvagem como precedente iconográfico seguro surge na xilogravura do panfleto ilustrado Dise Figur anzaigt uns das Folck und Insel (Augsburgo: Johann Froschaver, 1505), correspondente ao terceiro relato de Vespúcio. ${ }^{6} \mathrm{O}$ artista anónimo representa aqui uma comunidade de índios Tupinambá ocupados nos 
seus afazeres habituais. A imagem corresponde ao texto escrito que ilustra. A promiscuidade é mostrada através do casal que se abraça e beija, enquanto um deles ergue um membro decepado. Ao seu lado, um canibal isolado mastiga um braço com contentamento. As partes de corpos desmembrados que pendem das traves sobre a fogueira fazem igualmente referência ao canibalismo dos indígenas. Encontramos ainda nesta representação elementos que remetem para um modo de vida familiar e pacífico: dois índios com lanças e arcos parecem envolverse numa conversa íntima; uma mãe dá o colo a um bebé, enquanto outra criança se aproxima dela, sob o olhar protector de uma outra figura. A prática da agricultura é aludida através da planta de milho que um índio ergue, do lado esquerdo. As figuras estão devidamente enquadradas, e usam artefactos cuja representação esteve certamente dependente de uma observação directa: a planta de milho, os toucados verticais dos Tupinambá, os seus adornos e vestuário, são sem dúvida o resultado do contacto do gravador com esquissos feitos por testemunhas oculares, ou com os próprios artefactos importados na viagem e provavelmente enviados de Portugal para Augsburgo (Leitch, 2010, pp. 59-60).

O toucado e o saiote plumíferos e as faixas de penas nos tornozelos rapidamente se tornaram uma convenção usada para aludir à não-civilização. O índio brasileiro Tupinambá substitui-se ao homem selvagem e torna-se a imagemprotótipo pela qual são aferidas todas as outras representações do selvagem. Os habitantes de todos os territórios novos para a Europa, mesmo os asiáticos, são não poucas vezes representados com cocar e saiote de penas. Assim, os primeiros relatos impressos das viagens de Cristóvão Colombo e de Vespúcio (surgidos entre 1493 e 1505) e as imagens que os acompanhavam não reflectiam diferenças culturais reais entre os europeus e os povos indígenas, mas baseavam-se em imagens recicladas que acentuavam a sua suposta natureza belicosa e as suas tendências antropofágicas. (Leitch, 2010, pp. 63-64).

Como já foi referido, a distinção entre as Américas e a Ásia constituía um anacronismo para a época. As imagens estereotipadas dos habitantes de ambos os continentes, América e Ásia, misturavam frequentemente referências a ambos os territórios. A tendência dos artistas do Renascimento para representar todos os povos recém-descobertos com o toucado e o saiote de penas dos Tupinambá brasileiros, sem olhar à sua origem geográfica, tendência que o antropólogo William Sturtevant designou por tupinambização do mundo, contribuiu para acentuar esta confusão.?

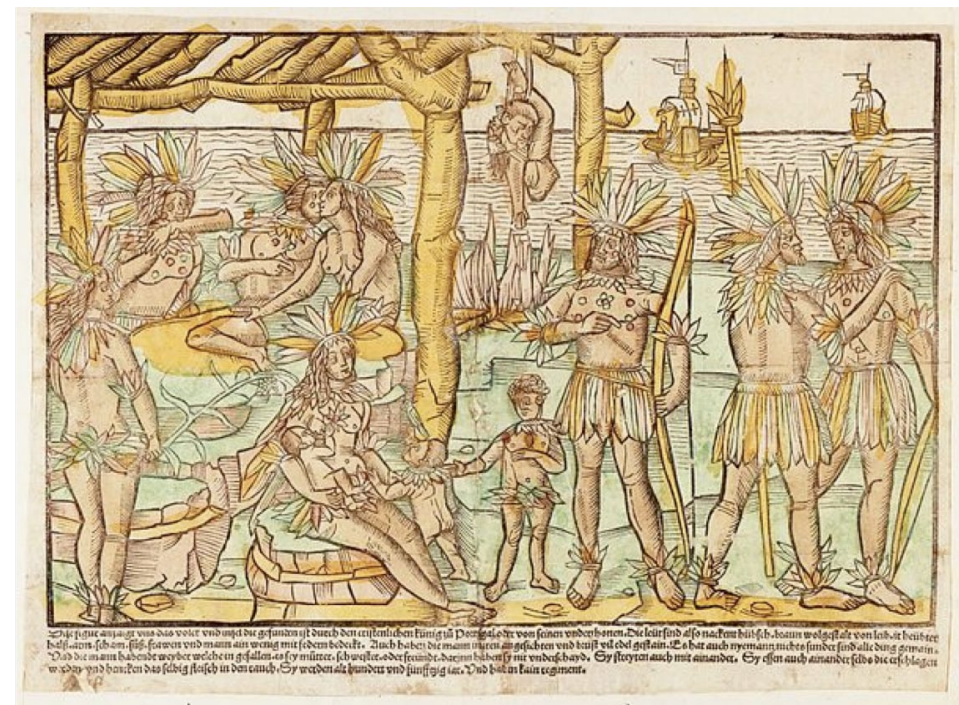

Fig.3 - Anónimo, ilustração com legenda: Dise Figur anzaigt uns das Folck und Insel...,

da obra Mundus Novus, atr. a Vespúcio (Augsburgo: Johan Froschaver, 1505). Xilogravura aguarelada à mão, $25.5 \times 35$ $\mathrm{cm}$. Bayerische Staatsbibliothek, Munique 
Num exemplar do Livro de Horas do Imperador Maximiliano, Albrecht Dürer desenhou, na margem do fólio 41, como ilustração do Salmo 24.1, um nativo do Novo Mundo com feições europeias e artefactos exóticos. ${ }^{8}$ Este livro foi impresso por Johannes Schonsperger em Augsburgo em 1513, e a ornamentação, acrescentada por Dürer a tinta violeta, data de 1515. O índio brasileiro é minuciosamente representado: rodeado de ramagens, onde se misturam pássaros exóticos e um caracol, assenta sobre o desenho de uma enorme colher de madeira, voltada ao contrário, um artefacto provavelmente alemão. Ao colocar o índio sobre a colher, talvez Dürer pretendesse assinalar, de acordo com o texto do próprio Salmo 24, que este receberia a benção do Senhor, dado que na época era costume os padrinhos oferecerem à criança que ia receber o dom do Espírito Santo a chamada "colher-apóstolo"; sendo um ser de mãos inocentes e puro coração, o índio pertenceria ao genus angelicum, juntamente com o turco, que figura, acompanhado do seu camelo, no fol. 42 verso da mesma obra (Kropfinger, 1990, pp. 457-487). O tacape, ou bastão de guerra cerimonial decorado com penas que empunha esta figura do índio, bem como o seu toucado de plumas, são tipicamente tupinambá, embora Dürer, desconhecendo a função do bastão, o alongue excessivamente, como se de uma lança se tratasse. Se bem que os nativos brasileiros andassem descalços e praticamente nus, Dürer representa o índio coberto com um saiote de plumas e calçado com sandálias de tipo africano. Este saiote de plumas, que segundo Massing nunca fez parte da indumentária tupinambá, seria claramente uma fantasia europeia, baseada nos artefactos chegados à Europa (as capas de plumas dos Tupinambá), e decalcada do saiote de folhagem que acompanha inúmeras figurações do homem silvestre; a sua função seria a de cobrir os genitália dos índios, e de permitir uma rápida identificação destas figuras com o mundo exótico e selvagem recém-descoberto. Os colares e pulseiras de penas e contas são típicos dos nativos brasileiros, mas as feições da personagem nada têm em comum com os indígenas da terra de Vera Cruz, sendo claramente europeizadas (Massing, 1991, pp. 515-520, e Massing, 1993, p. 223).

\section{No Triunfo do Imperador Maximiliano} (c. 1517-1518), Hans Burgkmair elaborou uma série de xilogravuras respeitantes ao cortejo triunfal, onde figuram igualmente, entre outros povos, os indígenas do Brasil. Estes encontram-se representados entre os habitantes de Calecute, termo que não se restringia à Índia, mas designava todos os povos das terras recém-descobertas, incluindo a América, que ainda era considerada parte do continente asiático. Aqui, à semelhança do que acontece na anterior miniatura de Dürer, também se misturam aspectos etnográficos distintos na figuração dos índios, que incluem toucados e saiotes/capas de penas e bastões de guerra tupinambá, juntamente com machados de metal e outras armas inexistentes entre os indígenas brasileiros.

No British Museum, conservam-se dois desenhos à pena sobre papel, datados de c. 1519-1525 (Massing, 1993, p. 223), e atribuídos igualmente a Hans Burgkmair; representam, respectivamente, um Jovem com fisionomia negróide vestido com saiote ameríndio e segurando um escudo asteca (desenho, pena e tinta negra, com aguada negra, castanha e cinzenta sobre papel, Inv. SL, 5218.128), e um Jovem com fisionomia negróide vestido com saiote ameríndio, capa e toucado de penas, empunhando uma lança com cabeça humana empalada na extremidade (desenho, pena e tinta negra, com aguada verde, castanha e cinzenta sobre papel, Inv. SL, 5218.129). Nestas figurações, a musculatura, o uso da perspectiva e as proporções do cânone figurativo renascentista são semelhantes às dos índios das xilogravuras do Triunfo do Imperador Maximiliano. Também aqui as capas de penas tupinambá são usadas incorrectamente como saiotes, para cobrir os genitália, e os cocares plumíferos, que deviam formar um halo à volta da cabeça, surgem colocados horizontalmente sobre o crânio e com a parte da frente para trás.

Um dos índios empunha um machadoâncora do Brasil e um escudo com 


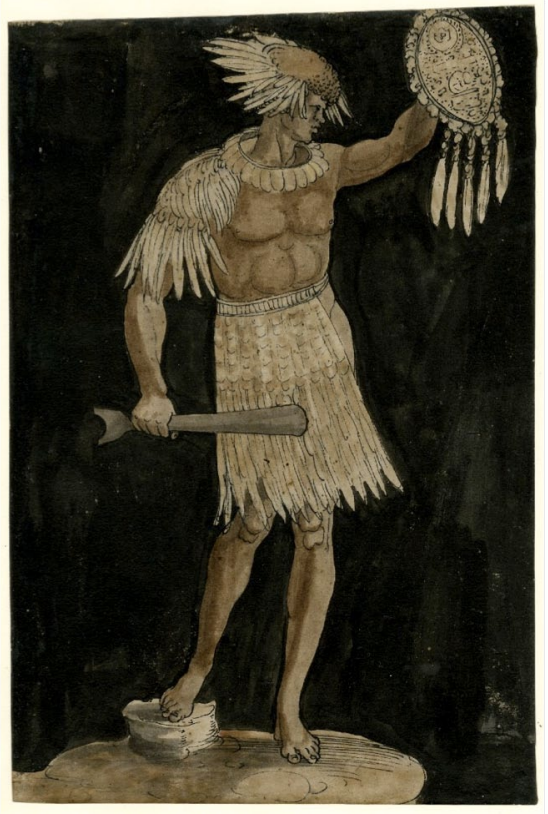

Fig. 5 - Hans Burgkmair o Antigo, Jovem com fisionomia negróide vestido com saiote ameríndio e segurando um escudo asteca, desenho, pena e tinta negra, com aguada negra, castanha e cinzenta sobre papel, 1520- 1530, 23,5×16 cm, The British Museum (Foto: The British Museum)

decoração em mosaico, provavelmente asteca, o que leva os especialistas a colocar este desenho em data posterior a 1519, ano da descoberta do México; talvez o escudo seja inspirado nos objectos vindos daquele território americano, que Dürer pôde observar em Bruxelas, em 1520, enviados por Hernán Cortéz. O outro índio empunha uma lança com uma cabeça "Tsantsa", própria dos caçadores de cabeças da tribo Jivaro do Equador, mas que estes usualmente usavam presa numa corda ao pescoço, e não empalada num bastão.

Estes desenhos de Burgkmair provam à exaustão a fluidez cultural comum a outras figuras híbridas que surgem em representações executadas por artistas germânicos por volta de 1515-1520. Tanto Burgkmair como Dürer estariam claramente familiarizados com os fragmentos de spolia ameríndios que constituem os artefactos por eles representados. São estes artefactos que thes permitem definir a identidade cultural dos povos do Novo Mundo, embora sem preocupações verdadeiramente etnográficas, como vimos. Apesar da exactidão com que são representados estes objectos, o seu uso correcto é quase sempre desconhecido ou ignorado pelos artistas; embora de origens diversas, estes objectos são misturados entre si sem exigência de rigor ou verismo. Há uma refuncionalização destes artefactos, usados como apontamento etnográfico para acentuar o exotismo das figurações híbridas: temos assim, por exemplo, um jovem de feições africanas, vestido à maneira brasileira, e segurando um escudo asteca. Estas técnicas de acomodação artística usadas para compor as representações dos povos que eram novidade para a Europa servem-se do vocabulário e da sintaxe de tipologias anteriormente familiares aos europeus (Leitch, 2010, p. 171).

Para além de Dürer, que viveu em estreito contacto com a feitoria portuguesa da Flandres durante a sua estada em Antuérpia, nos anos de 1520 e 1521, outros artistas alemães terão sido influenciados pelo exotismo resultante da expansão portuguesa. A feitoria portuguesa em Antuérpia era famosa entre as elites europeias, não só como importante plataforma comercial, mas também como fonte de preciosidades orientais e de objectos raros de colecção (Chauduri, 1998, p. 524).

Antuérpia desempenhava um papel fundamental na observação da realidade europeia, e as ligações entre Augsburgo e Portugal através desta cidade foram significativas durante o reinado de D. Manuel I. Os feitores portugueses em Antuérpia foram muitas vezes diplomatas de ocasião, ao representarem o país junto do Imperador da Alemanha e dos príncipes, e a sua presença em Augsburgo está bem documentada. Os Welser tinham a sua sociedade comercial estabelecida em Antuérpia, a partir de 1503, onde dirigiam as actividades comerciais relativas ao espaço atlântico com Lisboa, Sevilha e as colónias espanholas das Índias Ocidentais.

Os Fugger, outra importante família de mercadores e banqueiros de Augsburgo, também contactaram com o mundo 
português pela via de Antuérpia. Jacob Fugger não só fez parceria com os Welser no negócio com o rei D. Manuel I para armar os três navios para a viagem às Índias Orientais, como manteve uma feitoria em Lisboa, para onde exportava cobre, prata e outros produtos alemães (Kellebenz, 1979, pp.84-85). A biblioteca dos Fugger continha a maior colecção de livros sobre a história da expansão ibérica, com mais de 20 mil volumes magnificentes, reunidos por Hans Jacob e pelo seu irmão Ulrich (Chauduri, 1998, p. 526).

Ao abandonarem o mercado veneziano e ao voltarem-se resolutamente para os mercadores portugueses, estabelecendo alianças financeiras e comerciais, as grandes firmas de Augsburgo, como os Fugger, os Welser ou os Höchstetter, contribuíram para divulgar os nossos progressos no mundo ultramarino e ajudaram a despertar o interesse dos humanistas, cosmógrafos, cartógrafos e impressores alemães pelas viagens de exploração portuguesas.

Não foi apenas nas artes gráficas que os artistas de Augsburgo mostraram interesse pelos habitantes do Novo Mundo, no início do séc. XVI; no Museu do Louvre, em Paris, conserva-se um painel representando a Adoração dos Reis Magos, datado de 1510,9 atribuído ao pintor de Augsburgo Ulrich Apt - Antigo. Esta obra pictórica fazia parte de um retábulo do altar dedicado à Assunção da Virgem, na igreja de Santa Cruz daquela cidade alemã (Goulão, 2012). No papel do Rei Mago mais jovem, Gaspar, que se encontra bem no centro da composição, em lugar de particular destaque, o pintor retratou com realismo cuidado um índio sul americano, de cor parda, olhos rasgados, rosto anguloso e negros cabelos, longos e corrediços, cortados numa franja a direito sobre a testa. Não encontramos aqui a presença de qualquer elemento exótico, para além deste rosto belíssimo: o índio traja ricamente à europeia, e não apresenta toucado ou saiote de plumas, manilhas, armas ou quaisquer outros objectos de particular interesse etnográfico. ${ }^{10}$

Se compararmos esta figura de índio com o da famosa tábua da Adoração dos Magos do retábulo português da Sé de Viseu, atribuído a Vasco Fernandes e Francisco Henriques (1501-06), vemos que a figuração do rei índio da pintura viseense é muito mais convencional e idealizada; as suas características físicas têm pouco em comum com as dos Tupinambá do Brasil: trata-se de um ser etnicamente híbrido, uma mistura artificial de um negro, um europeu e um ameríndio. Não estamos face a um retrato, mas sim a uma construção idealizada, compósita, uma invenção europeia, criada por pintores de uma oficina portuguesa periférica, que provavelmente nunca tiveram a oportunidade de ver um Tupinambá de carne e osso; representam esta figura com um traje onde se misturam influências europeias convencionais - os calções de brocado e o gibão de seda - com a novidade exótica de um toucado de penas, ao qual não falta sequer a copazinha pequena de penas vermelhas e pardas como as dos papagaios, a que se refere Pero Vaz de Caminha na sua famosa Carta, bem como inúmeros colares de contas coloridas, grossas manilhas de ouro nos pulsos e tornozelos, brincos de coral branco, um remate de penas idênticas às do toucado, no decote e na franja do corpete, e uma flecha tipicamente tupinambá, com o seu longo cabo. Este índio de Viseu segura ainda uma taça feita de noz de coco montada em prata, o que reforça o carácter exótico do conjunto. Percebemos aqui a presença de curiosa e exotica, pertencentes talvez ao círculo erudito do comitente, sendo que o pintor se serve destes objectos reais, a que provavelmente teve acesso, para compor a sua figuração do índio. Alguns destes elementos, como o cocar e o saiote de penas a condizer, são, como já vimos, auxiliares visuais significativos na composição do motivo convencional da figura do índio do Brasil.

Associa-se esta figuração benigna do Rei Mago índio como "bom selvagem" à perspectiva idílica de diversos relatos do encontro com os Tupinambá, em que a nudez e a inocência destes testemunham a sua bondade intrínseca e os relacionam com o Paraíso perdido. Esta figuração 
parece pois transmitir a ideia de que os índios eram criaturas de Deus, passíveis de conversão religiosa. ${ }^{11}$

Mas voltemos à imagem do painel de Ulrich Apt o Antigo: apesar da aparência atraente do jovem rei ameríndio, um lado mais sombrio da sua natureza é sugerido pelo detalhe do gato que espreita através da manga do seu gibão. Na literatura renascentista do norte da Europa, encontramos um uso abundante e difundido da expressão "espreitar pela manga", geralmente com a conotação de "revelar a sua verdadeira natureza". 0 gato pode, assim, sugerir as características

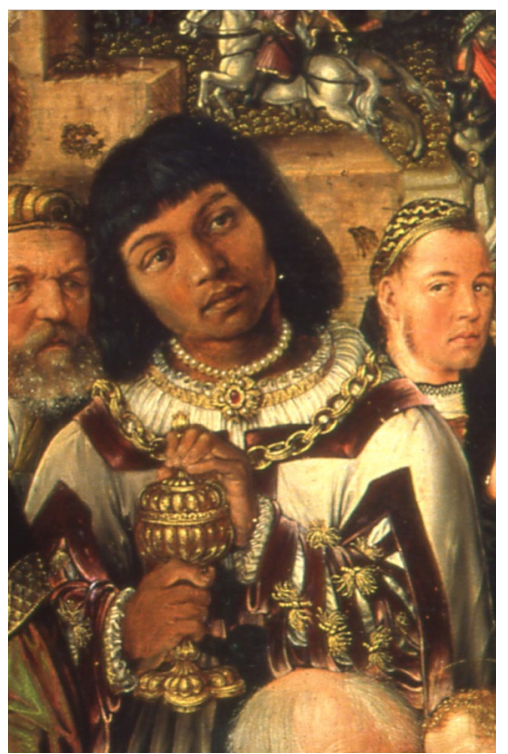

Fig.6 - Ulrich Apt-o-Antigo, Adoração dos Magos (detalhe), retábulo de Santa Cruz de Augsburgo, c. 1510, óleo s/ madeira, 125x71 cm, Museu do Louvre, Paris (Foto: Réunion des Musées Nationaux - Agence Photographique)

obscuras que convencionalmente caracterizam o mais jovem dos Reis Magos, tradicionalmente negro, cor associada aos indivíduos pecaminosos, demoníacos, ou praticantes de rituais mágicos (Pinson, 1996, p. 161). Nesta composição, a alusão diabólica que espreita subrepticiamente para fora da manga do jovem Rei ameríndio contrasta com a assunção da bem-aventurança dos restantes magos e da sua comitiva, que correspondem a um conjunto de dez retratos dos membros da corporação dos tecelões de Augsburgo, os patronos da obra em questão. Com efeito, uma crónica de 1623 refere que o tríptico do qual este painel fazia parte fora encomendado pelo rico burguês de Augsburgo, Weber Martin Weiss, e pela sua mulher Elisabeth, em 1510. Muito provavelmente, o próprio Martin Weiss, tecelão de profissão e um dos fundadores do importante grémio dos tecelões da cidade, serviu de modelo para o Rei Mago que se encontra de pé, em primeiro plano, à esquerda, na Adoração dos Reis Magos. Esta afirmação é reforçada pelo facto de o retratado aparecer igualmente representado numa pintura votiva da autoria de Leonhard Beck, conservada no Augsburger Maximilianmuseum, e que apresenta traços fisionómicos idênticos. Feuchtmayr coloca a hipótese de o rapaz que se encontra representado no painel do Louvre do lado esquerdo do Rei Mago índio, com a mão levantada, ter as feições do jovem Ulrich Fugger (Feuchtmayr, 1928, p. 97 e 107).

Não deixa ainda de ser notável a parecença física entre o jovem de barrete vermelho exuberantemente rematado com plumas brancas que integra a comitiva dos Reis Magos, e o Retrato de Anton Welser o Jovem, realizado em 1527 na mesma cidade alemã pelo pintor Christoph Amberger, pintura que integra a colecção da família Welser. ${ }^{12} \mathrm{Em}$ 1510, data da execução do painel de Augsburgo, Anton Welser o Jovem, nascido em 1486, tinha 24 anos, uma idade perfeitamente plausível para o jovem retratado na Adoração dos Reis Magos de Apt. Foi ele o representante máximo da sociedade comercial desta família de banqueiros de Augsburgo, primeiro em Lyon e, a partir de 1503, em Antuérpia, ocupando-se dos negócios relativos ao espaço atlântico, que incluíam Lisboa, Sevilha e as colónias espanholas nas Américas. Convém recordar que tanto os Fugger como os Welser estabeleceram vários acordos de comércio vantajosos com o monarca português, e participaram activamente no intercâmbio com Portugal, onde os Welser chegaram a ter seis funcionários permanentes em Lisboa, e uma feitoria na ilha da Madeira. É pois 
natural que estivessem particularmente atentos às novidades do espaço atlântico. O impressor alemão Valentim Fernandes, já referido, manteve ligações epistolares com o humanista Konrad Peutinger, que por sua vez era casado com uma irmã deste Anton Welser o Jovem. Valentim teve um importante papel como tradutor, agente e informador das viagens de Lisboa para a Índia junto dos Welser (Curto, 1998, p.443), e é provável que nos manuscritos ou cartas por ele enviados para Augsburgo ou Nuremberga tenha seguido informação detalhada relativa aos índios brasileiros.

Em contraste com o naturalismo da representação do índio no painel da Adoração dos Magos de Augsburgo, por volta de 1523 o pintor flamengo Jan Mostaert pintava em Malines uma curiosa obra, Paisagem com um episódio da conquista da América, que mostra a visão fantasiosa destas terras de além-mar que persistia junto de alguns eruditos e artistas dos Países Baixos: aqui, encontramos uma paisagem montanhosa idêntica a tantas outras dos pintores flamengos, muito longe dos horizontes tropicais, um mar esverdeado e um céu nublado como no Norte, e vegetação e animais domésticos europeus, que se misturam com um macaco e papagaios. Nesta paisagem, um grupo de homens barbudos equipados com flechas, arcos, bastões e pedras, e de mulheres nuas, ainda fortemente marcados pelo protótipo do homem selvagem, defendemse dos invasores espanhóis, que avançam da costa bem equipados, em fileiras cerradas (Bernand e Gruzinski, 1991, pp. 217-218).

Alguns dados aos quais os historiadores da arte têm sido pouco sensíveis, e que merecem ser aprofundados, podem permitir equacionar um contacto directo precoce de artistas franceses e alemães com os Ameríndios, acontecido em território europeu, que terá eventualmente moldado algumas destas figurações, como aliás sucedeu com os nativos das Índias Orientais: sabemos que um grupo de indianos da costa do Malabar estaria vivo e de boa saúde, a viver na região da Suábia, no início do séc. XVI (Leitch, 2010, p. 2). Em Portugal, que mantinha, como vimos, contactos muito estreitos com a Alemanha e os Países Baixos, logo em 1511 encontramos Fernão de Loronha, titular da real concessão para explorar o pau-brasil, a desembarcar vindo do Brasil com um carregamento de índios brasileiros escravizados (Navarro-Swain, 2000, p. 178).

Segundo o Auto Notarial de Valentim Fernandes, já em 1503 havia em Bruges uma representação plástica (uma imagem daqueles homens, i.e., um desenho ou escultura) dos índios do Brasil, juntamente com uma pele de crocodilo, trazidas na viagem de regresso de Pedro Álvares Cabral daquele território, em 1501-1502, e oferecidas à capela do Sangue de Cristo, naquela cidade da Flandres, por João Drabe (Andrade, 1972, p. 545). ${ }^{13}$

É igualmente sabido que em agosto de 1520 Dürer pôde apreciar, no palácio real de Bruxelas (outra grande cidade europeia elevada nesta altura a centro incontestável do mundo ocidental), os primeiros tesouros astecas entregues aos espanhóis pelos emissários de Montezuma, que Hernán Cortéz enviara do Novo Mundo para a corte do Imperador Carlos V, e que haviam já causado admiração em Valladolid uns meses antes. Estes tesouros foram depois mostrados em público, juntamente com seis Astecas (ou, mais correctamente, Mexicas), aquando da coroação de Carlos V em Aachen, em outubro de 1520. Com a subida ao poder de Carlos V, é verdadeiramente a Europa do Norte que se abre à aventura americana, e o México faustoso que desembarca pela primeira vez nos Países Baixos (Bernard e Gruzinski, 1991, pp. 213214).

As descrições destes espólios mexicanos são verdadeiramente impressionantes; num outro manuscrito da época, cujo original é em castelhano (António Herrera, $3^{a}$ Década, Livro III. Madrid, 1725-1726, traduzido para francês por Guenin, 1901 . pp. 19-20), menciona-se os objectos saqueados pelos espanhóis aquando da conquista da capital asteca, Tenochtitlán, em 1521, e igualmente enviados a Carlos $\checkmark$ : Une esmeraude fine, aussi large que 
la paume de la main; un ameublement de vaisselle d'or et d'argent, comme des tasses, des vases, des plats, des escuelles, des pots et d'autres pièces où étaient gravées des figures d'oyseaux, de poissons et autres animaux de divers genres, et d'autres en façon de fruits et de fleurs; quantité d'anneaux, de pendants d'oreilles, de carcans, de colliers et d'autres joyaux tant pour hommes que pour femmes, et quelques idoles avec des sarbacanes d'or et d'argent; des masques à la mosaïque de pierres fines avec les oreilles d'or et les dents d'os qui surpassaient les lèvres; des vêtements de prestres, des mitres, un corporalier, des ornements d'autel et autres parements de plume et de coton, des os de géants; des tigres, dont l'un s'échappa dans le navire, blessa huit hommes, en tua deux et se jeta dans la mer; et furent contraints de tuer l'autre, de crainte qu'il ne fit la même chose.

Os enviados de Cortéz nesta ocasião, d'Ávila, Quiñones e Mendoza, que haviam partido de Villa Rica de la Vera Cruz, em terras mexicanas, em três caravelas transportando o referido tesouro asteca para ser entregue a Carlos $V$, foram aprisionados em 1523 junto ao arquipélago dos Açores por corsários franceses, comandados por Jean Fleury, a mando de Jean Ango, que tomaram duas das naus. Enviadas aos Açores mais três caravelas espanholas comandadas por Domingo Alonso, para proteger o ouro que restava e os pobres oficiais espanhóis, Alonso d'Ávila, Quiñones e os passageiros sobreviventes, encarregados de o fazer chegar a bom porto, a dez léguas do cabo S. Vicente foram novamente atacados pelo corsário francês Jean Fleury, que não tinha perdido a sua presa de vista. As três caravelas foram aprisionadas pelos piratas. António de Quiñones morreu na batalha naval que se seguiv; Alonso d'Ávila foi levado a La Rochelle no navio dos piratas, e aí ficou 3 anos prisioneiro (Guenin, 1901, pp. 20-23).

Quanto ao destino dos Astecas/Mexicas exibidos em Aachen no outono de 1520, nada é dito, mas desde o início do séc. XVI que os indígenas da América eram trazidos com frequência para a Normandia, local de origem dos corsários que atacaram as naus com os tesouros mexicanos. Em 1508, em Roven, aquando da entrada real de Luís XII, sete indígenas americanos já haviam sido mostrados em público (Wintroub, 2001, p. 483). No ano seguinte, é registrada em Roven a presença de indígenas brasileiros, ali chegados com um dos capitães ao serviço da frota de Jean Ango, Thomas Aubert.

Para além do testemunho que Dürer nos deixou do seu deslumbramento face às primeiras riquezas enviadas a Carlos $V,{ }^{14}$ estas curiosidades americanas, ou os próprios prisioneiros ameríndios, influenciaram certamente as várias representações de índios que se encontram em Dieppe e Roven, que atestam a importância das ligações ao Brasil para a economia local normanda, através da pirataria e do comércio. No friso dos selvagens de uma das paredes da capela do tesouro da igreja de Saint Jacques de Dieppe, datado de cerca de 1530, fazse referência, através da figuração dos habitantes daquelas regiões, às expedições empreendidas pelos navegadores e marinheiros desta cidade, no Novo Mundo, em África e em Sumatra. Na primeira parte do friso, os Tupinambá do Brasil são facilmente identificáveis graças aos cocares de penas que envergam. Estas figurações permitem-nos entrever o ambiente que reinava em Dieppe e em Roven no tempo dos grandes corsários e comerciantes como Jean Ango ou os irmãos Verrazane. Foi sob a égide de Jean Ango, patrono da igreja de Dieppe, que se esculpiu o friso dos selvagens de Saint Jacques.

Em Roven, a importância das ligações americanas para a economia local encontrava-se igualmente patente noutras imagens dos índios brasileiros. As embarcações de Jean Ango e outros armadores da região mantinham uma ativa exploração de pau-brasil junto aos indígenas no litoral dos atuais estados do Rio Grande do Norte, Pernambuco e Paraíba. A fachada do imponente palacete do $n^{\circ} 17$ da rua de Malpalu era ornamentada com baixos-relevos em madeira representando os nativos do Brasil, com corpos nus de 
feição maneirista, a extrair o pau-brasil, que se ocupam a embarcar numa caravela, a mando dos comerciantes de Roven. Realizados cerca de 1530, estes relevos podem ser vistos actualmente no Musée Départemental des Antiquités daquela cidade. Na capela da Virgem, na catedral de Notre Dame de Roven, no túmulo dos cardeais de Amboise, arcebispos de Roven (c. 1515-1520), o escultor, Rouland Le Roux, integrou dois índios do Brasil armados de arcos e flechas e toucados de plumas, por entre a simbólica religiosa, permitindonos deduzir que estavam em Rouen nessa altura, ou que o artista tinha podido observá-los algures na região. ${ }^{15}$ No túmulo de Louis de Brézé, o marido da famosa Diane de Poitiers, obra da autoria de Jean Goujon, de cerca de 1530, e que se encontra igualmente na catedral de Roven, surge também um motivo de grotesco com uma cabeça de índio estilizada, fazendo pendant com uma cabeça de anjo, numa clara oposição de carácter emblemático entre o Mal e o Bem, respectivamente.

Jean Ango, o famoso corsário (ou pirata, aos olhos dos portugueses), armador e mercador com ligações ao Novo Mundo, e parceiro de negócios de Jean Fleury, albergava um contingente de indígenas americanos no seu castelo normando, La Pensée, situado na localidade que é hoje Varengeville-sur-Mer, nas décadas de 30 e 40 do séc. XVI. Se bem que um pouco mais tardio, um dos mais famosos textos de Michel de Montaigne relata o seu encontro com vários índios do Brasil trazidos para Roven aquando da visita de Carlos IX em 1562, índios estes que viveriam em nudez total no bairro de Saint Sever, em Roven (Wintroub, 2001, p. 481).

Era frequente que Colombo, Cortéz e outros descobridores, aventureiros e conquistadores promovessem cortejos nas ruas das cidades europeias, apresentando às multidões os artefactos e produtos exóticos, bem como os índios feitos prisioneiros, que eram obrigados a desfilar. Em 1520, Jean Parmentier, um navegador, cartógrafo e poeta de Roven, compôs uma mômerie para celebrar o tratado de paz entre Francisco I e Henrique VIII, que foi representada em Dieppe, tendo ficado muito célebre. Os objectos que foram usados nesta mascarada, descritos nos relatos da época, terão vindo certamente do espólio do corsário Jean Ango: são grifos adornados de ouro fino, pedras preciosas, grandes lâminas de ouro talhadas em forma de serpentes e outros animais, um dossel adornado de penas coloridas, feito por índios e trazido das Índias Ocidentais, que lembram o espólio proveniente dos galeões espanhóis aprisionados três anos mais tarde pelos corsários de Roven, a mando de Jean Ango. Trata-se sem dúvida de objectos das Índias Ocidentais e Meridionais, i.e. do México, das Antilhas e do Brasil, onde Parmentier tinha igualmente navegado e comerciado em nome do monarca francês. Certamente que os marinheiros de Dieppe que assistiam a esta representação organizada por um dos seus conheciam a proveniência dos objectos exibidos; trata-se de um desfile triunfal destinado a estimular o orgulho colectivo, pondo em evidência os mais brilhantes feitos destes homens do mar (Guenin, 1901, pp. 112-118).

Também na Fête Brésilienne, ou Fête du Nouveau monde, celebrada em Rouen em 1550, aquando da recepção oferecida pela cidade a Henrique II e Catarina de Médicis, foi feito uso de verdadeiros ameríndios para recriar um village brésilien: cabanas de troncos, arbustos pintados de vermelho para se assemelharem às árvores do pau-brasil, verdadeiros papagaios e saguins misturaram-se com trezentos habitantes da cidade de Roven, homens e mulheres, todos inteiramente nus. Cinquenta eram autênticos "selvagens" trazidos do Brasil por um mercador de Roven com ligações ao Novo Mundo. As suas maçãs do rosto, orelhas e lábios estavam perfurados e ornados de pedras polidas brancas e verdes, uma prática característica dos Tupinambá. Os restantes eram marinheiros normandos mascarados de selvagens: asseguraram ao rei que o seu retrato era fiel, pois não só haviam percorrido as terras do Brasil, como haviam aprendido a língua dos nativos e adoptado os seus costumes, de tal maneira que não se conseguia distingui-los dos verdadeiros selvagens. Os "Brasileiros" (Brésiliens, nos 
relatos da época) descansavam à sombra das árvores, balançavam-se nas suas redes e caçavam macacos. Outros estavam ocupados a cortar o pau-brasil, que depois trocavam por machados, anzóis e tesouras de ferro, num forte construído para o efeito e ocupado pelos marinheiros franceses. De repente, um grupo de selvagens que se intitulavam Tabagerres (Tobajara) juntaram-se à volta do seu chefe, a quem chamavam Morchiba na sua língua, ouviram-no atentamente, e puseramse a combater com matracas e flechas atacando um bando rival, os Toupinabaulx (Tupinambá). As duas tribos lutaram de forma tão verosímil que os espectadores do combate que já tinham viajado até ao país do Brasil e dos Canyballes juraram de boa fé que esta reconstituição revestia un certain simulachre de la vérité (Wintroub, 2001, pp. 480-481).

O sentido da representação de 1550 em Roven é acima de tudo o de evidenciar os interesses económicos em jogo: nesta entrada real, a afirmação do poder da monarquia francesa e a construção de uma mitologia nacional são reforçados pela encenação do confronto entre os portugueses e os franceses, reforçado numa batalha naval, igualmente apresentada, entre um navio francês e uma caravela portuguesa. Esta complexa trama narrativa punha face a face as alianças existentes no Novo Mundo: os Tupinambá, aliados dos franceses, respondiam aos Tobajara, amigos dos portugueses (Wintroub, 2001, pp. 483484).

Em conclusão, temos assim, na primeira metade do séc. XVI, um curto período em que algumas regiões da Europa, não necessariamente as que mais se destacavam por lutarem de forma particularmente acesa pelo controlo dos restantes continentes, demonstraram um profundo interesse pelos povos nãoeuropeus, contribuindo decisivamente para desmantelar uma cartografia de centralidade definida, a ideia de uma hierarquia pré-estabelecida para a dignidade humana e uma visão estereotipada destes homens. Esta breve e precoce expressão de relativismo cultural não foi de longa duração, nem se estendeu a todo o território europeu; degradar-se-á com alguma rapidez com a chegada do imperialismo, das políticas de conquista e ocupação, e do absolutismo político. Neste contexto, a cidade de Augsburgo foi um centro notável de investigação etnográfica sobre os povos estrangeiros; os relatos vernaculares dos primeiros contactos, sobretudo os de Cristóvão Colombo e de Vespúcio, encontraram aqui grande aceitação, circulando amplamente e permitindo aos artistas, pintores, gravadores e impressores alemães, como Hans Burgkmair, a criação de um modelo iconográfico destes nativos logo nas primeiras décadas do séc. XVI. Estas imagens deram um contributo significativo para a conquista do mundo visível e dos seus povos, através de figurações do Outro que caldeiam convenções normalizadoras, textos das Maravilhas do Oriente há muito em circulação, e iconografia solidificada a partir de modelos visuais anteriormente usados para tipos folclóricos estabelecidos, como o homem selvagem. Embora inicialmente seja perceptível a tentação de classificar a novidade recorrendo a categorias familiares, a figura do índio vai emergindo da sombra do homem selvagem e vai-se moldando às especificações irregulares dos textos de descoberta; dáse pouca atenção ao naturalismo, mas à medida que chegam à Europa artefactos americanos que complementam a informação das testemunhas presenciais dos primeiros encontros, inclui-se spolia, exotica e outras curiosidades nas figurações, acabando o cocar e saiote de penas por se tornar um distintivo iconográfico bastante comum, pois permite a criação de uma imagem mais específica e verídica para aludir à alteridade (Leitch, 2010, pp. 6, 54 e 177-179).

No caso da pintura de Ulrich Apt o Antigo, temos uma representação do nativo americano que, se não é desprovida de preconceitos e negativismo, parece baseada num estudo dos particularismos étnicos e no método de observação directa, estabelecendo o conceito visual da testemunha ocular, que encontramos igualmente nas narrações escritas mais 
precoces, escritas na primeira pessoa, do encontro com outros povos. A visão expressa no conjunto dos retratos do painel de Santa Cruz de Augsburgo é a de uma certa heterogeneidade social, cultural e étnica, permitindo defender que estamos em presença de uma sensibilidade protoetnográfica, embora provavelmente mais ligada aos comitentes do que ao artista em si.

Se parece haver aqui uma adesão dos artistas e dos eruditos de Augsburgo à crença humanista na possibilidade de se conhecer o mundo através de tentativas sistemáticas de o organizar, estudar, preservar e reproduzir, o mesmo não sucede em França, onde as representações do Ameríndio não apresentam o mesmo grau de fidelidade ao real nem idênticas preocupações proto-etnográficas, posicionando-se antes, como sucede em Portugal, como herdeiras dos temas exóticos mais ou menos inócuos para divertimento das elites, ou como símbolo da prosperidade de determinados grupos sociais, conseguida através do saque, do corso e do comércio no eixo do Atlântico Sul. Quando as figurações têm finalidades moralizadoras, como no caso do famoso painel do Inferno, obra de oficina portuguesa cosmopolita, possivelmente do primeiro quartel de Quinhentos (Museu Nacional de Arte Antiga, Lisboa), não é à representação naturalista do índio que o artista recorre, mas apenas aos seus atributos distintivos, neste caso as penas coloridas, que ornamentam e vestem Lúcifer, o símbolo do Mal, que preside ao desenrolar da cena, bem como outro diabo coxo que transporta às costas um frade sodomita acorrentado ao seu jovem amante. A simples utilização desta convenção visual associada à figuração do índio é suficiente para criar no observador a associação pretendida, ajudando a definir os demónios e os condenados ao Inferno como seres próximos da pura bestialidade, heréticos, libidinosos e incapazes de dominar os seus instintos mais primários.

Convém, no entanto, ter presente que estes contactos iniciais da Europa com o Novo Mundo não se processam sistematicamente em termos de Eu-Outro, com o indígena americano a ocupar o lugar do Outro, antes de mais por ser difícil discernir uma identidade homogénea europeia própria no Renascimento. Da mesma forma que a Europa não era uma entidade monolítica e uniforme, também não havia necessariamente um discurso organizado sobre o "nativo"; o conhecimento inicial deste Outro segue neste particular a lógica ainda habitual do saber renascentista: é articulado não através de narrativas que se opunham, mas sim recorrendo habitualmente à lógica da semelhança (Seth, 2010, pp. 35-36 e 59).

\section{Notas}

Este texto é o resultado de uma conferência que foi acompanhada da projecção de várias dezenas de imagens. Devido a limitações editoriais, o grosso dessas imagens e a informação que as acompanhava foram excluídas neste formato. Por questões de espaço, o presente texto cinge-se à figuração do índio, deixando de fora a figura do negro, que foi igualmente abordada na conferência, e que será objecto de publicação futura.

A autora gostaria de agradecer ao Professor António de Sousa Ribeiro as sugestões de leitura. O texto não segue o novo Acordo Ortográfico.

(1) Borch, Knudsen, Leer e Ross, 2008, p. xix. Sobre a questão do corpo, cf., entre outros: Ballantyne e Burton, 2005, Borch, Knudsen, Leer e Ross, 2008, Fraser e Greco, 2004, Mascia-Lees, 2011.

(2) A New World was made to mirror a very old and, in the reflection, could be identified the signatures of similitude. The vast repository of medieval monsters, pagan practices, cannibal feasts, and Golden Age innocence offered a selfreferential medium between the new continent and the Christian canons, indigenous cultures, and ancient commentaries. (Seth, 2010, p. 58) (3) Conchas, peles de animais, bastões e papagaios são mencionados por Konrad Peutinger, o humanista e secretário da cidade de Augsburgo, numa missiva destinada a Sebastian Brant (König, 1923, pp. 77-78). Numa anotação escrita pelo próprio Peutinger na margem do seu exemplar da Cosmografia de Ptolomeu, encontra-se uma das primeiras referências a escravos do Índico no continente europeu. Esta nota refere a compra pelo sogro 
de Peutinger, Anton Welser, juntamente com outros dois membros de famílias de comerciantes de Augsburgo, Ambrosius Höchstetter e Konrad Vöhlin, de nativos indianos da costa do Malabar, que estariam vivos e de boa saúde, a viver na região da Suábia. Burgkmair, dada a proximidade a estes círculos, pode bem tê-los usado como modelos para as suas gravuras (Leitch, 2010, p. 2). A respeito das relações entre comerciantes, humanistas e artistas, cf., entre outros, Goulão, 2012, pp. 86-89.

(4) Leitch, 2010, pp. 212-214. Cf. também José Pereira da Costa (ed. de), Códice Valentim Fernandes, Lisboa: Academia Portuguesa da História, 1997.

(5) Cf., a este respeito, Gruzinski, 1999, e em particular as pp. 236-237.

(6) A carta de Américo Vespúcio a Lorenzo di Pier Francesco de Medici, de julho de 1502, conhecida como Mundus Novus, onde se fala dos índios americanos, embora de autenticidade duvidosa, foi publicada primeiro em Paris em 1503, e um ano depois em Augsburgo, sendo depois traduzida para alemão e neerlandês em 1505. Esta xilogravura alemã, colorida nos dois exemplares conservados, foi executada em Augsburgo ou Nuremberga em 1505 para a edição deste texto da carta Mundus Novus (Chicangana-Bayona, 2010).

(7) Cit. em Feest, 1987, p. 610. Cf. ainda Sturtevant, 1988.

(8) O exemplar em questão encontra-se na Bayerische Staatsbibliothek, em Munique. Sobre este fólio, cf. Strauss, 1974, p. 81, e Massing, 1993. (9) O painel da Adoração do Menino, que fazia parte do mesmo retábulo, conserva a data de 1510 na parte da frente da pedra que se encontra pintada à esquerda, em primeiro plano. A data não é facilmente legível, não apresentando contudo quaisquer dúvidas (Lauts, 1966, pp. 31-32).

(10) Embora esta obra tenha sido várias vezes exposta e estudada, nunca nenhum autor descortinou a figuração do índio. Apenas Feuchtmayr (1928, p.110) se refere a esta figura como Mohrenkonig, isto é, o rei mouro. Também no Ficheiro Demonts do Museu do Louvre, na descrição da obra, se menciona um roi maure Gaspar.

(11) Para o estudo de outras figurações do índio na arte portuguesa do Renascimento, que não cabem neste trabalho, cf. Goulão, 1988 e Goulão, 1999.

(12) Cf. a reprodução deste quadro em Álvarez
Nogal, 1999, p. 618.

(13) Transcrição: O egrégio varão João Draba manda essa imagem, isto é, daqueles homens, e a presente [pele] de crocodilo - em memória do sereníssimo Rei - à capela do sangue de Cristo, constituída em Bruges, cidade da Flandres, para louvor de Deus omnipotente e da pátria, no mês de maio do ano da salvação de 1503. (Amado e Figueiredo, 2012)

(14) Para a tradução em inglês do original em alemão do diário de Dürer, cf. Goris e Marlier, 1971 , p. 64

(15) Segundo Bonet Correa (1968, pp. 179-180), os índios que surgem no túmulo dos cardeais de Amboise seriam figurações baseadas nas máscaras de ouro astecas que o corsário Jean Ango de Dieppe mandara apresar no ataque às três caravelas espanholas que transportavam o tesouro asteca visto por Dürer. Ora é impossível que o tesouro visto por Dürer em 1520 fosse o mesmo apresado por Jean Ango, dado que este acto de pirataria só acontece em 1523. Trata-se certamente de dois carregamentos diversos.

\section{Bibliografia}

Albuquerque, L. de (1990), Pero Vaz de Caminha and the Brazilian American indian (pp. 33-41). In La imagen del índio en la Europa moderna. [s.I.]: CSIC.

Álvarez Nogal, C. (1999), Las remesas americanas y los banqueros de la Monarquía. In El oro y la plata de las Indias en la época de los Austrias (pp. 607-623). Madrid: Fundación ICO.

Amado, J. e Figueiredo, L. C. (2012), A Certidão de Valentim Fernandes, documento pouco conhecido sobre o Brasil de 1500, Textos de História. Revista do Programa de Pósgraduação em História da UnB., 5 (2), 133-142. Disponível em: http://seer.bce.unb.br/index. $\mathrm{php} /$ textos/article/view/5872/4853 (acedido em: 15/07/ 2013)

Andrade, A. A. B. de (1972), O Auto Notarial de Valentim Fernandes (1503) e o seu significado como fonte histórica. Arquivos do Centro Cultural Português, vol. V, 521-545.

Ballantyne, T. e Burton, A. (Eds.). (2005), Bodies in Contact. Durham, NC: Duke University Press.

Bernard, C. e Gruzinski, S. (1991), Histoire du Nouveau Monde, vol. I, De la découverte à la conquête, une expérience européenne, 1492 1550. Paris: Fayard.

Bonet Correa, A. (1968), Integracion de la cultura indigena en el arte hispanoamericano. In 
España en las crisis del arte europeo (pp. 179188). Madrid: Instituto Diego Velázquez.

Borch, M. F.; Knudsen, E. R.; Leer, M. e Ross, B. C. (2008), Introduction. In Merete Falck Borch, Eva Rask Knudsen, Martin Leer e Bruce Clunies Ross (Eds.), Bodies and Voices. The ForceField of Representation and Discourse in Colonial and Postcolonial Studies (pp. xvii- xl). Amsterdam/New York, NY: Rodopi.

Borch, M. F.; Knudsen, E. R.; Leer, M. e Ross, B. C. (Eds.). (2008), Bodies and Voices. The ForceField of Representation and Discourse in Colonial and Postcolonial Studies. Amsterdam/ New York, NY: Rodopi.

Borges, N. C. (2001), Arte monástica em Lorvão: sombras e realidades, vol. I, Das origens a 1737. [s.I.]: Fundação C. G./JNICT.

Chauduri, K. (1998), A recepção europeia da expansão. In Francisco Bethencourt e Kirti Chauduri (Orgs.), História da expansão portuguesa, vol. I, A formação do Império (1415-1570) (pp. 512-533). [s.l.]: Círculo de Leitores.

Chicangana-Bayona, Y. A. (2010), Visões de terras, canibais e gentios prodigiosos. Uberlândia, 12 (21), 35-53. Disponível em: http://www.artcultura.inhis.ufu.br/PDF21/y bayona.pdf (acedido em 20/09/2013)

Costa, J. P. da (Ed.). (1997), Códice Valentim Fernandes. Lisboa: Academia Portuguesa da História.

Dudley, E., e Novack, M. E. (1972), The Wild Man Within: An Image in Western Thought from the Renaissance to Romanticism. Pittsburgh: University of Pittsburgh Press.

Erickson, P. (1993), Representations of Blacks and Blackness in the Renaissance. Criticism, 35 (4), 499-528. Disponível em: http://www.slavernijonline.nl/download/ peterson_blackinrenaissance.pdf (acedido em 26/09/2013)

Farago, C. (1995), 'Vision Itself Has Its History': 'Race', Nation and Renaissance Art History. In Claire Farago (Ed.), Reframing the Renaissance. Visual Culture in Europe and Latin America, 1450-1650 (pp. 67-88). New Haven and London: Yale University Press.

Feest, C. F. (1987), Indians and Europe: an Interdisciplinary Collection of Essays. Aachen: Rader Verlag.

Feuchtmayr, K. (1928), Apt-Studien. In Ernst Buchner e Karl Feuchtmayr, Augsburger Kunst der Spätgotik und Renaissance (pp. 97-132).
Augsburg: Dr. Benno Filser Verlag G.M.B.H.

Fraser, M. e Greco, M. (Orgs.). (2004), The Body: A Reader. Florence, Kentucky, U.S.A.: Routledge.

Goris, J. A. e Marlier, G. (Eds.). (1971), Albrecht Dürer. Diary of his Journey to the Netherlands, 1520-1521. Accompanied by the silverpoint sketchbook and paintings and drawings made during his journey. London \& New York: Lund Humphries.

Goulão, M. J. (1988), Do mito do Homem Selvagem à descoberta do Homem Novo: a representação do negro e do índio na escultura manuelina. In Pedro Dias (Coord.), Actas do IV Simpósio Luso-Espanhol de História da Arte - Portugal e Espanha entre a Europa e Além-Mar (pp. 321-345). Coimbra: Instituto de História da Arte - Universidade de Coimbra.

Goulão, M J. (1999), Do homem selvagem ao índio brasileiro: a construção de uma nova imagem da humanidade na arte europeia de Quinhentos. In Luis Donizete Benzi Grupioni (Org.), A carta de Pero Vaz de CaminhaDocumentos e ensaios sobre o achamento do Brasil (pp. 173-195). São Paulo: Xerox do Brasil / DBA Dórea Books and Art.

Goulão, M. J. (2012), As primeiras imagens do índio brasileiro no espaço europeu: a Adoração dos Magos de Ulrich Apt o Antigo do retábulo de Santa Cruz de Augsburgo. População e Sociedade. Estudos de Arte e Património. 20, 78-91.

Greenblatt, S. (1991), Marvelous Possessions. The Wonder of the New World. Chicago: The University of Chicago Press.

Gruzinski, S. (1999), La pensée métisse. Paris: Fayard.

Guenin, E. (1901), Ango et ses pilotes, d'après des documents inédits, tirés des archives de France, de Portugal et d'Espagne. Paris: Imprimerie Nationale.

Kellebenz, H. (1979), Fuggers em Portugal. In Joel Serrão (Ed.), Dicionário de História de Portugal vol. I (pp. 84-86). [s.I.]: Iniciativas Editoriais/ Livraria Figueirinhas.

König, E. (1923), Konrad Peutingers Briefwechsel. Munich: Beck.

Kropfinger, H. von K. (1990), El índio: bárbaro y/o buen salvaje? In La imagen del índio en la Europa moderna (pp. 457-487). [s.I.]: C.S.I.C.

Lauts, J. (1966), Karlsruhe Alte Meister bis 1800. Karlsruhe. 
Leitch, S. (2010), Mapping Ethnography in Early Modern Germany: New Worlds in Print Culture. New York: Palgrave Macmillan.

Mascia-Lees, F. E. (Ed.). (2011), A Companion to the Anthropology of the Body and Embodiment. Chichester: Blackwell Publishing.

Massing, J. M. (1991), Early European images of America: the ethnographic approach. In Circa 1492: Art in the age of exploration (pp. 515-520). Washington/ New Haven and London: National Gallery of Art/ Yale University Press.

Massing, J. M. (1993), Albrecht Dürer's Irish Warriors and Peasants. Irish Arts Review. Yearbook 1994. X, 223-226.

Mitchell, W. J. T. (1991), Iconology, Ideology, and Cultural Encounter: Panofsky, Althusser, and the Scene of Recognition. In Claire Farago (Ed.), Reframing the Renaissance. Visual Culture in Europe and Latin America, 1450 1650 (pp. 292-300). New Haven and London: Yale University Press.

Navarro-Swain, T. (2000), Las representaciones mentales del descubrimiento de Brasil. In Franklin Pease, G.Y. e Frank Moya Pons (Dirs.), Historia general de America Latina, vol. II, El primer contacto y la formación de nuevas sociedades (pp. 172-195). Paris: Ediciones Unesco/Editorial Trotta.

Pereira, D. P. (1988), Esmeraldo de Situ Orbis. Lisboa: Academia Portuguesa de História.

Pereira Iglesias, J. L. (1993), La imagen del índio en el viejo mundo. In María de las Nieves Muñiz Muñiz (Org.). Espacio geografico, espacio imaginário: el descubrimiento del Nuevo Mundo en las culturas italiana y española (pp. 175-185). Cáceres: Universidad de Extremadura.

Pina, R. de (1977), Crónicas. Porto: Lello e Irmão.

Pinson, Y. (1996), Connotations of Sin and Heresy in the Figure of the Black King in Some Northern Renaissance Adorations. Artibus et Historiae, 17 (34), 159-175.

Sebastián, S. (1990), El índio desde la iconografia. In La imagen del índio en la Europa moderna (pp. 433-455). [s.I.]: C.S.I.C.

Sebastián López, S. (1988), Iconografia Medieval. Donostia: Editorial Etor.

Seth, V. (2010), Europe's Indians: Producing Racial Difference, 1500-1900. Durham and London: Duke University Press.
Strauss, W. L. (Ed.) (1974), The Book of Hours of the Emperor Maximilian the First: Decorated by Albrecht Dürer, Hans Baldung Grien, Hans Burgkmair the Elder, Jörg Breu, Albrecht Altdorfer, and Other Artists. Printed in 1513 by Johannes Schoensperger at Augsburg. New York: Abaris Books.

Sturtevant, W. (1988), La Tupinambisation des indiens d'Amérique du Nord. In G. Thérien (Ed.), Les Figures de l'Indien (pp. 293-303). Montréal: Université du Québec à Montréal.

Vasconcelos, J. F. de (1867), Memorial das proezas da segunda Távola Redonda ( $2^{a}$ ed.). Lisboa: Tipografia Panorama.

Vigarello, G.; Courtine, J. J. e Courbin, A. (Eds.) (2008), História do Corpo. 3 vols. Petrópolis: Vozes.

Wintroub, M. (2001), L'ordre du rituel et l'ordre des choses : l'entrée royale d'Henri II à Roven. Annales. Histoire, Sciences Sociales, $56 e$ année, n. 2, 479-505. Disponível em: http://www.persee.fr/web/revues/home/ prescript/article/ahess_0395-2649_2001 num_56_2_279958 (acedido em 28/06/2013) 